\title{
Differential identification of three species of Curtovirus using loop-mediated isothermal amplification
}

\author{
E.-J. KIL ${ }^{1}$, S.-H. CHO ${ }^{1}$, H.-S. BYUN ${ }^{1}$, J. KIM ${ }^{1}$, H.-S. HWANG', C.-K. AUH ${ }^{2}$, N.-Y. HEO ${ }^{3}$, Y.-G. SHIN ${ }^{3}$, S. LEE ${ }^{*}$
}

${ }^{1}$ Department of Biotechnology and Bioengineering, Sungkyunkwan University, Suwon 440-746, Korea; ${ }^{2}$ Department of Biological Sciences, Mokpo National University, Muan 534-729, Korea; ${ }^{3}$ Plant Quarantine Technology Center, Department of Animal and Plant Health Research, Animal and Plant Quarantine Agency, Suwon 443-400, Korea

Received July 29, 2013; accepted May 20, 2014

\begin{abstract}
Summary. - Rapid and sensitive detection methods for three species of Curtovirus were developed using a loop-mediated isothermal amplification (LAMP) technique. A universal primer set for detecting the three main species of Curtovirus at the same time, and three kinds of species-specific primer sets were designed and used for LAMP reactions. Results from the LAMP reactions were visualized both by color changes after adding SYBR Green I staining dye and by DNA laddering on agarose gel electrophoresis. The optimal conditions for the curtovirus LAMP reaction were confirmed at $60^{\circ} \mathrm{C}$ for the universal primers and at $62^{\circ} \mathrm{C}$ for the three species-specific primer sets. Amplification of curtoviruses by LAMP reaction was ten-fold more sensitive than that by polymerase chain reaction. Primers designed for curtovirus detection in this study did not anneal to or amplify DNA from other DNA or RNA viruses (tomato yellow leaf curl virus, tomato spotted wilt virus, and potato virus $\mathrm{Y}$ ). Taken together, the primer sets and reaction conditions developed in this study show that the LAMP technique could be a useful tool to detect the three species of Curtovirus simultaneously and distinguish them in the laboratory and the field.
\end{abstract}

Keywords: beet curly top virus; Curtovirus; detection; Geminivirus; loop-mediated isothermal amplification

\section{Introduction}

Curtovirus, a genus of the family Geminiviridae, has single-stranded circular DNA genome encoding several genes in opposite directions encapsidated by a twin icosahedral (geminate) capsid structure, which can be transmitted by leafhoppers (Stanley et al., 1986). Beet curly top virus (BCTV), a member of the genus Curtovirus, causes curly top disease (CTD) in more than 300 plant species from 44 different families (Bennett, 1971). The typical symptoms of BCTV are stunting, leaf yellowing and curling, and vein swelling in several hosts, including the sugar beet (Stanley and Latham,

*Corresponding author. E-mail: cell4u@skku.edu; phone: +82-31290-7866.

Abbreviations: $\mathrm{BCTV}=$ beet curly top virus; $\mathrm{BMCTV}=$ beet mild curly top virus; BSCTV = beet severe curly top virus; LAMP = loopmediated isothermal amplification
1992). Three distinct strains of BCTV have been studied, California/Logan, CFH, and Worland (Stenger, 1998). These strains have the same wide host range and are transmitted by the same leafhopper species, but share about $80 \%$ nucleotide sequence identity and show differential pathogenicity in sugar beet plants (Stanley et al., 1986; Stenger and Ostrow, 1996; Stenger, 1998; Soto and Gilbertson, 2003). Stenger studied differences among the three main BCTV strains and reported taxonomic and nomenclatural problems with the three strains (Stenger and Ostrow, 1996; Stenger, 1998). Because of their differential pathogenicity in plants and the more divergent sequences of nucleotides in complementary sense genes and the intergenic region compared to those of the virion sense, they became three separate species and were renamed (Stenger et al., 1998, 1990; Fauquet and Stanley, 2003; Soto and Gilbertson, 2003). The California/Logan strain retained its name as $\mathrm{BCTV}$, the $\mathrm{CFH}$ strain became beet severe curly top virus (BSCTV), and the Worland strain 
was designated beet mild curly top virus (BMCTV) (Stenger, 1998; Soto and Gilbertson, 2003).

The number of reported curtoviruses has increased continuously; therefore, methods to detect and distinguish curtoviruses are required for further studies. Even though some studies on curtoviruses in the field have dealt with PCR primer sets for distinguishing the three main species of Curtovirus (BCTV, BSCTV, and BMCTV) (Strausbaugh et al., 2008; Chen et al., 2010), application of other methods for detecting and distinguishing curtoviruses has not yet been reported. Several methods based on nucleic acid amplification or antibody-antigen-specific interactions have been used to detect viruses from infected plants. Both methods have been used in complementary ways to diagnose viral diseases (Crowther, 1998). Although rapid, specific, and sensitive tools for detecting plant pathogens have been developed due to recent advances in molecular biotechnology, all of these techniques have some disadvantages such as high cost, multiple steps and possible false-negatives and positives (Miller and Martin, 1988; Weiss, 1995). Serological detection methods have been utilized for on-site detection, because these techniques do not demand long periods of time, multi-steps, complicated machines, or specialists for the experiments (Torrance and Jones, 1981; Weiss, 1995). For example, strips based on the antibody-antigen interaction have been used for testing plant viruses (Danks and Barker, 2008). However, they lack sensitivity, so PCR-based methods, which are 100-fold more sensitive than ELISA, have been used for more sensitive detection in the laboratory (Minsavage et al., 1994). In most cases, the disadvantages of one technique may be strengths of other methods and vice versa; thus, minimizing the number of disadvantages has been a perennial problem of detection methods.

In this study, we provide primer sets not only for detecting three species of Curtovirus simultaneously, but also for distinguishing among these three species of Curtovirus. We also optimized the LAMP reaction conditions using total genomic DNA isolated from virus-infected plants. We show that the LAMP reaction provides higher specificity and sensitivity of virus detection than PCR.

\section{Materials and Methods}

Virus species and plant inoculation. The three main Curtovirus species, namely BCTV (previously called the California/Logan strain), BSCTV (CFH strain), and BMCTV (Worland strain), were used in this study. Information on the infectious clones of these three species has been described previously (Stenger et al., 1990). The three kinds of clones were provided by Dr. Drake C. Stenger (Agricultural Research Service, United States Department of Agriculture, Parlier, CA, USA). Each clone was transferred to Agrobacterium tumefaciens strain GV3101 using a freeze-thaw procedure and incubated in YEP media at $28^{\circ} \mathrm{C}$ for 2 days. Two-week-old Nicotiana benthamiana and four-week-old Arabidopsis, which are model host plants, were pricked about 5-10 times on the apical meristem using fine needles, and inoculum was dropped onto the meristems to infect the plants (Elmer et al., 1988). Leaf samples were harvested 35 days after agro-inoculation. Virus agro-inoculations were conducted in a restricted area in the Plant Quarantine Technology Center, Department of Animal and Plant Health Research, Animal and Plant Quarantine Agency, Korea.

DNA extraction from infected plants. Total DNA was extracted from leaves of virus-infected Nicotiana benthamiana as previously described (Dellaporta et al., 1983).

LAMP primer design. Two inner primers and two outer primers are needed for the LAMP reactions, (Notomi et al., 2000); therefore, the LAMP primer sets used to detect the three virus species (BCTV [GenBank Acc. No. M24597.2], BSCTV [GenBank accession number U02311.1], and BMCTV [GenBank accession number U56975.1]) separately were designed based on the uploaded sequences of each virus from GenBank using PrimerExplorer version 4 (http://primerexplorer.jp/elamp4.0.0/index.html). The multiple sequence alignment ClustalW2 program (http://www. ebi.ac.uk/Tools/msa/clustalw2/) results of the nucleic acids of the three species were used as the input instead of each sequence to construct a universal primer set to detect the three virus species of Curtovirus.

Optimization of LAMP conditions. LAMP reactions were carried out in $20 \mu \mathrm{l}$ reaction mixtures at 60,62 , and $65^{\circ} \mathrm{C}$ for $60 \mathrm{~min}$, followed by heat inactivation at $80^{\circ} \mathrm{C}$ for $5 \mathrm{~min}$. The reaction mixtures contained $0.8 \mu \mathrm{mol} / \mathrm{l}$ each of the inner primers of FIP and BIP, $0.2 \mu \mathrm{mol} / \mathrm{l}$ each of the outer primers of $\mathrm{F} 3$ and $\mathrm{B} 3,0.8 \mathrm{mmol} / \mathrm{l}$ of each dNTP, $1 \mathrm{~mol} / \mathrm{l}$ betaine (Sigma-Aldrich, St. Louis, MO, USA), $4 \mathrm{mmol} / \mathrm{l} \mathrm{MgSO}_{4}, 8 \mathrm{U}$ Bst DNA polymerase large fragment (New England Biolabs, Beverly, MA, USA), $1 \times$ ThermoPol $^{\text {th }}$ reaction buffer (10×, New England Biolabs), and the specified amount of the target viral DNA in a final volume of $20 \mu \mathrm{l}$. The results were analyzed by colorimetric changes and agarose gel electrophoresis. A color change to fluorescent green was detected in infected samples after adding $1 \mu \mathrm{l}$ 10,000× SYBR Green I Nucleic Acid Gel Stain (Invitrogen, Carlsbad, CA, USA). Every experiment was repeated at least three times.

LAMP specificity and sensitivity. LAMP primer specificity was evaluated using $100 \mathrm{ng}$ of total DNA prepared from BSCTV-and tomato yellow leaf curl virus (TYLCV)-infected plants, and $100 \mathrm{ng}$ cDNA synthesized from total RNA isolated from tomato spotted wilt virus (TSWV)- and potato virus $Y$ (PVY)-infected plants as templates. Diluted DNA samples $\left(1-10^{-8}\right)$ were used as LAMP and PCR templates to conduct the LAMP sensitivity assay, and to compare the results to those of PCR. PCR amplification was performed with $20 \mu \mathrm{l}$ reaction mixtures comprising $0.5 \mu \mathrm{mol} / \mathrm{l}$ each of the F3 and B3 outer primers for LAMP, $375 \mu \mathrm{mol} / \mathrm{l}$ of each dNTP, Super Taq DNA polymerase (Rexgene Biotech Co., LTD, Seoul, Korea), and $1 \times$ the supplied reaction buffer (10×, Rexgene Biotech). PCR amplifications were carried out as follows: pre-denaturation at 
$94^{\circ} \mathrm{C}$ for $5 \mathrm{~min}$, followed by 35 cycles each at $94^{\circ} \mathrm{C}$ for $30 \mathrm{sec}, 55^{\circ} \mathrm{C}$ for $30 \mathrm{sec}$, and $72^{\circ} \mathrm{C}$ for $30 \mathrm{sec}$. Each experiment was performed at least three times.

Results

Optimization of the reaction conditions for detecting Curtovirus

A universal primer set (Curto-F3, Curto-B3, Curto-FIP, and Curto-BIP), based on conserved sequences of three species, was used to detect the three species of Curtovirus (Fig. 1, Table 1). Reactions with this primer set were carried out for $60 \mathrm{~min}$ at 60,62 , and $65^{\circ} \mathrm{C}$, respectively, using DNA samples isolated from BCTV-, BSCTV-, and BMCTV-infected $N$. benthamiana (Fig. 2) and Arabidopsis Col-0 at 35 days after inoculation. The most conclusive results were shown when the reactions were performed at $62^{\circ} \mathrm{C}$ for $60 \mathrm{~min}$ using the three templates prepared equally from each virus-infected plant, whereas colorimetric changes after adding SYBR Green I and bands such as the DNA ladder markers on the agarose gel appeared faintly at $60^{\circ} \mathrm{C}$, and did not appear at $65^{\circ} \mathrm{C}$ (Fig. 3).

LAMP reactions for the three species of Curtovirus using the specific primer sets (Table 1) were performed with the virusspecific primer sets, and the three viral genomic DNAs were isolated from the three virus-infected plants at 60,62 , and $65^{\circ} \mathrm{C}$ individually after 1 hour. Laddering and color changes to green occurred only in reactions with samples from BCTV-infected plants at 60 and $62^{\circ} \mathrm{C}$, but better results were obtained at $60^{\circ} \mathrm{C}$ (Fig. $4 \mathrm{a}$ and b). The optimal LAMP reaction conditions with the BMCTV-specific primer set (Table 1) were assessed under the same conditions. Tubes containing gDNA from BMCTVinfected tobacco produced the brightest green color after adding SYBR Green I, as well as the most intense DNA fragments on an agarose gel when the reactions were conducted at $60^{\circ} \mathrm{C}$ for $60 \mathrm{~min}$ (Fig. $4 \mathrm{c}$ and $\mathrm{d}$ ). The same results were obtained for BMCTV-specific primers (Table 1, Fig. 4e and f). Following

(a)

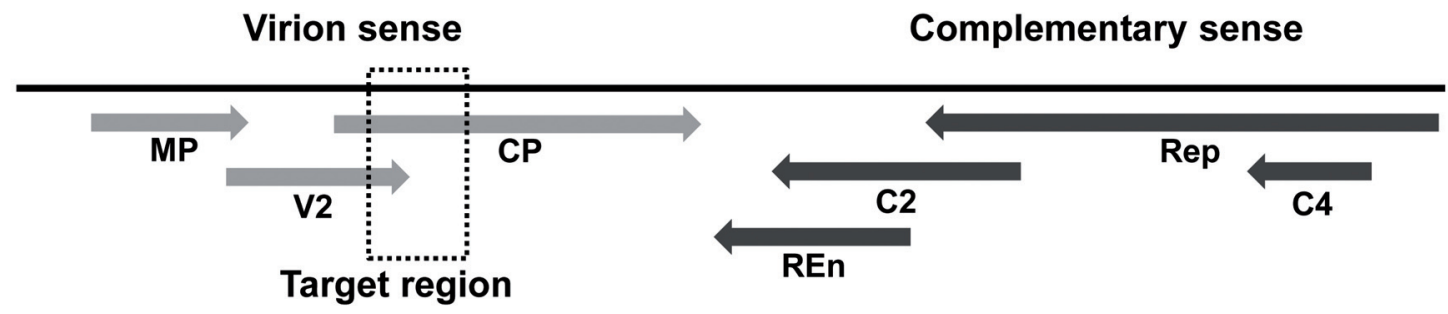

(b)

BCTV .... ATATACAAGAAATACGTATACAATGTCCCAGAAAAGAAAGGTGAATCCTCAAAGTGCGTGGCCGAAGAAGAGGAGGACTAGTACGA

BSCTV .... ATATACAAGAAATACGTATACAATGTCCCAGAAAAGAAAGGTGAATCCTCAAAGTGCGTGGCCGAAGAAGAGGAGGACTACTACGA

BMCTV .... ATATACAAGAAATACGTATACAATGTCCCAGAAAAGAAAGGTGAATCCTCAAAGTGC TTGGCCGAAGAAGAGGAGGACTACTACGA
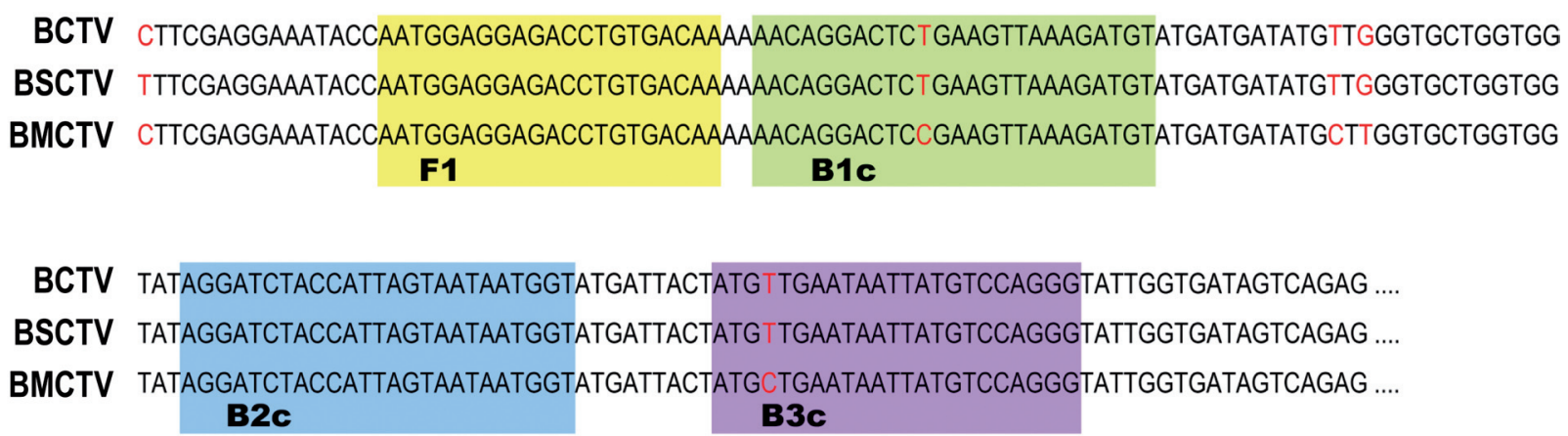

Fig. 1

Primers and their target sequences for LAMP of three species of Curtovirus (beet severe curly top virus [BSCTV], beet curly top virus [BCTV], and beet mild curly top virus [BMCTV])

(a) Full-length viral genome of three curtoviruses and the target region of the LAMP reaction (dotted box). (b) Multiple alignment of three curtovirus sequences near the target sequence and primer sets (colored boxes). 


\begin{tabular}{|c|c|}
\hline Primer name & Sequence $\left(5^{\prime}-3^{\prime}\right)$ \\
\hline \multicolumn{2}{|c|}{ Curtovirus (Universal) } \\
\hline Curto-F3 & AAT CCT CAA AGT GCK TGG \\
\hline Curto-B3 & CCC TGG ACA TAA TTA TTC ARC AT \\
\hline Curto-FIP & TTG TCA CAG GTC TCC TCC ATT CCG AAG AAG AGG AGG ACT A \\
\hline Curto-BIP & AAC AGG ACT CYG AAG TTA AAG ATG TAC CAT TAT TAC TAA TGG TAG ATC CT \\
\hline \multicolumn{2}{|l|}{ BCTV } \\
\hline BCTV-F3 & GTT TGT CTG CCA CTC CTT \\
\hline BCTV -B3 & AGA GGG TGA TTC AAG AAC AG \\
\hline BCTV -FIP & TCA TTG ATG ACG TAG ATC CCA CTT ATT GTG CTC CAA TAA GGT GT \\
\hline BCTV -BIP & CGT TCT AGG GCT AAA ATC TAA GTG CGG AAG ACT ATG TGG GCT AG \\
\hline \multicolumn{2}{|r|}{ I } \\
\hline BSCTV-F3 & CCT GCA TTT AAT GCC TCT G \\
\hline BSCTV -B3 & AAG TAC CAG CAA ACA ATT CC \\
\hline BSCTV -FIP & GTG AAT TTC AGG TCG ATG GAA GAC TGC AGC ATC ATT AGC CG \\
\hline BSCTV -BIP & CCA GTC GAT GTG ATC TCC GTA CTG CAA TAT TCA GGG AGC \\
\hline \multicolumn{2}{|r|}{ I } \\
\hline BMCTV-F3 & ACT AAA ATC TAA ATG CCC TGA A \\
\hline BMCTV-B3 & ACC TCC ATT CCC ACA ATC \\
\hline BMCTV-FIP & GCG CGG CCT TTT AGA TAT AAT AGT AGG TCC TAA TGA TCT AGC CCA \\
\hline BMCTV-BIP & CGG CAT CCA CCC CGA AAT AAT CTT TCA CTC AAG TTC CAG A \\
\hline
\end{tabular}

these results, optimal conditions for the three primer sets were confirmed to be $60^{\circ} \mathrm{C}$ for $60 \mathrm{~min}$ for each set.

Comparison of the sensitivity of LAMP and PCR methods for Curtovirus

Serial dilutions of DNA extracted from BSCTV-infected leaf tissues of $N$. benthamiana and Arabidopsis Col-0 were used as a template to compare the amplification sensitivity between LAMP and PCR. The F3 and B3 primers (Fig. 1 and Table 1) were used for PCR instead of other primers to achieve the same targeted sequence position and length. The results showed that DNA at the $10^{-6}$ dilution was detectable by both the LAMP and PCR methods (Fig. 5). The LAMP reaction was more sensitive than PCR, a product was obtained for the more diluted template DNA (at $10^{-7}$ dilution), as shown by agarose gel electrophoresis (Fig. 5).

\section{Specificity of LAMP detection}

Specific amplification of the target sequence is one of the most important aspects of a detection method. We selected a representative DNA virus belonging to the family Geminiviridae (TYLCV), and two RNA viruses (TSWV and PVY) as targets for reactions using genomic DNA or cDNA synthesized from total RNA samples from BSCTV, TYLCV, TSWV, and PVY-infected leaf tissues in order to test the specificity of the LAMP reaction primer set, which was designed only for Curtovirus using the previously confirmed conditions for the universal primer set. After the amplification reactions, SYBR
Green I was added, and the samples were loaded on a $1 \%$ agarose gel. No green color or DNA laddering was observed in the TYLCV, TSWV, or PVY samples, but the reaction with genomic DNA isolated from BSCTV-infected tissue was bright green in color (Fig. 6a) and showed laddering (Fig. 6b). These results indicate that the LAMP reaction with the universal primer set was specific for detecting curtoviruses.

\section{Discussion}

Although many powerful techniques modified from PCR and ELISA have been developed to detect viruses and other pathogens, reports are available about detecting curtoviruses using only classical methods such as PCR (Strausbaugh et al., 2008; Chen et al., 2010). Most studies on Curtovirus focused mainly on phenotypic and genotypic characterization, viral protein functions, comparisons of symptom severity and sequences among the three main species (originally strains), and plant-virus interactions (Stanley et al., 1986; Stenger, 1998; Soto and Gilbertson, 2003; Hur et al., 2008; Park et al., 2010). However, new technologies are needed to detect and identify Curtovirus species, which will help protect economically important crops. Among the many detection techniques reported, LAMP technology can be used for on-site detection, producing specific and sensitive results from a small amount of sample. The LAMP assay is a time- and cost-saving, accurate method to amplify nucleic acids (Notomi et al., 2000). Many studies have, therefore, introduced primer sets and LAMP methods for detecting plant DNA and RNA viruses 
(a)

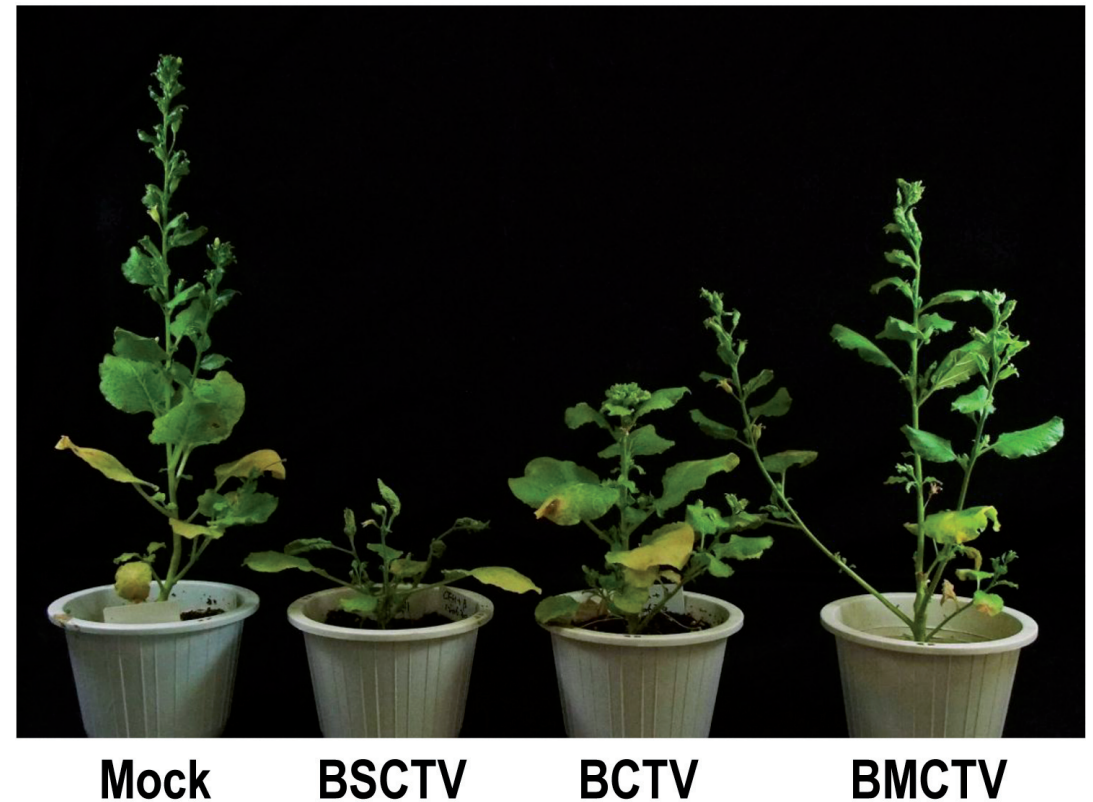

(b)

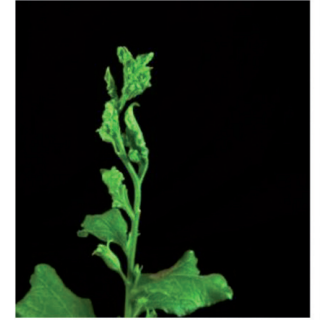

(c)

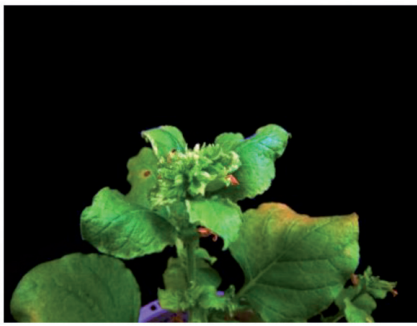

Fig. 2 (d)

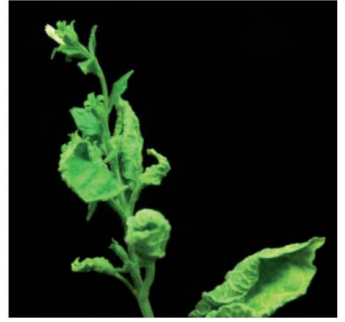

Symptoms of infected N. benthamiana by (b) BSCTV, (c) BCTV, and (d) BMCTV at 35 days after inoculation and (a) a comparison of the plants

Fig. 3

LAMP of each DNA for detection of the three Curtovirus species at three different temperatures $(60,62$, and $65^{\circ} \mathrm{C}$ ) using universal primers that can be used to amplify all types of curtovirus DNA

Tubes for visual observations that have amplified products from (a) N. benthamiana and (b) Arabidopsis samples with SYBR Green I under UV light. (c) DNA gel staining with ethidium bromide. Lane N, no template control. (a)

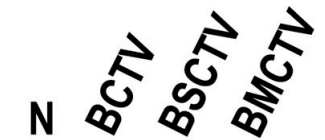

)

(b)

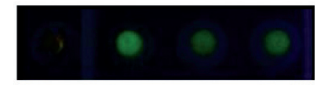

(c)

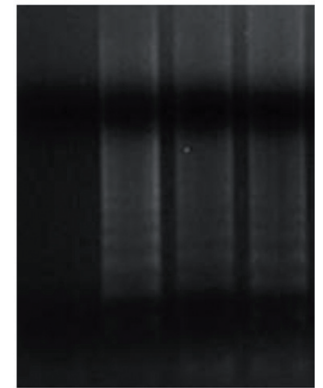

$60^{\circ} \mathrm{C}$
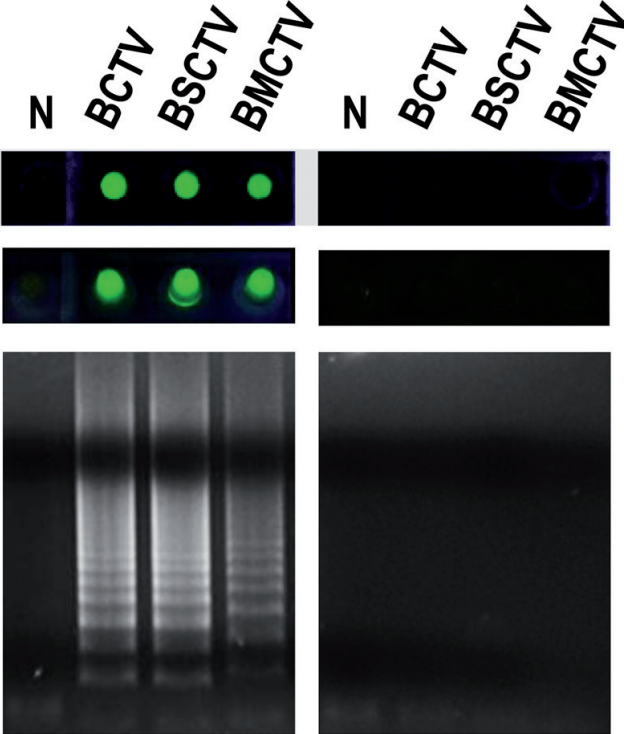

$62^{\circ} \mathrm{C}$
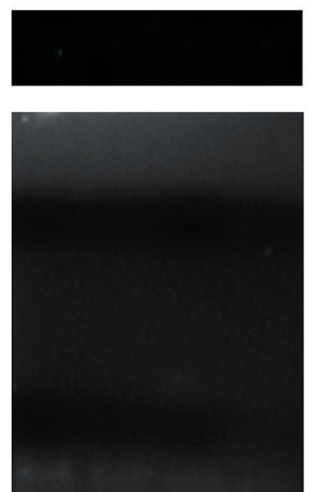

$65^{\circ} \mathrm{C}$ 
(Nie, 2005; Kuan et al., 2010). Specifically, DNA viruses in the genus Begomovirus, such as TYLCV and squash leaf curl virus (SLCV), have been amplification targets using the LAMP method, and these viruses are detectable from infected plants and viruliferous whiteflies (Bemisia tabaci) (Fukuta et al., 2003; Kuan et al., 2010; Hsieh et al., 2012).

This study investigated a universal LAMP primer set for detecting Curtovirus species simultaneously, and the three LAMP primer sets for distinguishing the three species of Curtovirus that proved useful in identifying and distinguishing the curtoviruses. The isothermal conditions required by LAMP could be met simply by using a water bath, so it is possible to instantly evaluate the virus detection results from many samples by just adding SYBR Green I staining dye to the amplified reaction solution without the gel electrophoresis step to visualize the reactions (Nie, 2005). These advantages will allow virologists, regardless of the background or work experience, to detect and diagnose Curtovirus correctly, easily, and rapidly in the field or laboratory. The primer sets and optimized LAMP reaction conditions developed in this study will be very helpful in detecting and distinguishing the Curtovirus species together and separately anywhere and anytime.

Acknowledgements. This study was supported partially by a grant (Project Code No. Z-1541785-2012-12-03) from the Animal, Plant \& Fisheries Quarantine and Inspection Agency, Ministry of Food, Agriculture, Forestry and Fisheries, Republic of Korea in

(a)

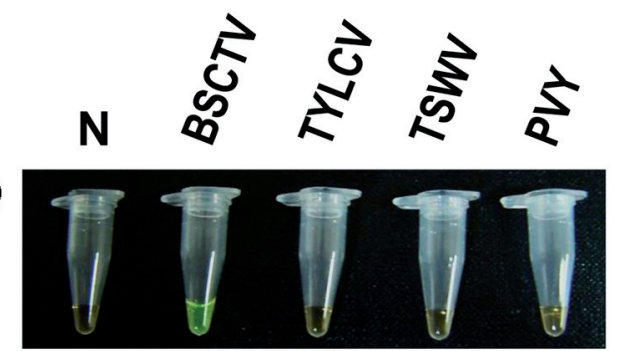

(b)

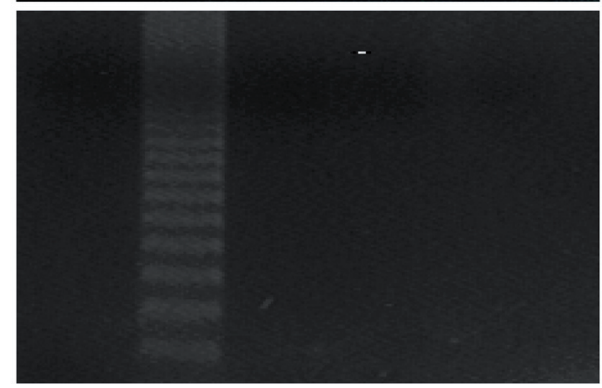

Fig. 6

LAMP specificity test using other viruses (beet severe curly top virus [BSCTV], tomato yellow leaf curl virus [TYLCV], tomato spotted wilt

virus [TSWV], and potato virus Y [PVY]-infected plant samples)

(a) Tubes for visual observations that have amplified products with SYBR Green I under visible light. (b) DNA gel staining with ethidium bromide. Lane N, no template control. (a)

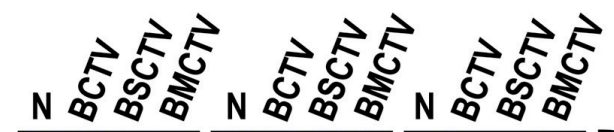

(b)
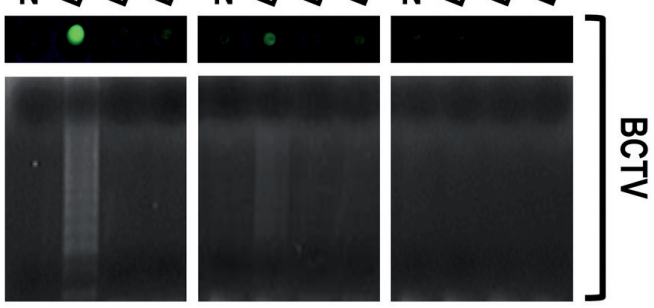

(c)
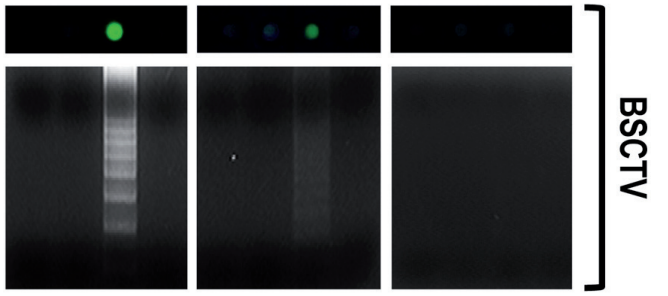

(e)
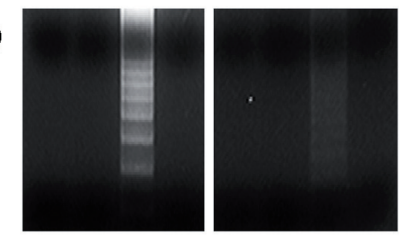

$\underset{2}{2}$

(f)

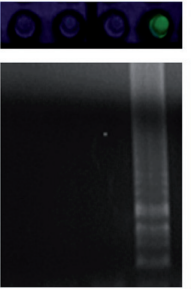

$60^{\circ} \mathrm{C}$

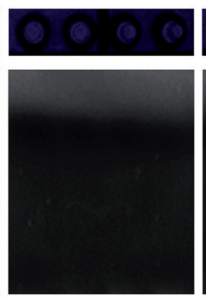

$62^{\circ} \mathrm{C}$

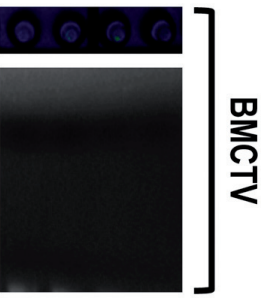

$65^{\circ} \mathrm{C}$

Fig. 4

LAMP at three different temperatures $\left(60,62\right.$, and $\left.65^{\circ} \mathrm{C}\right)$ using three kinds of specific primers for each species (BCTV [(a) and (b)], BSCTV $[(\mathrm{c})$ and $(\mathrm{d})]$, and BMCTV $[(\mathrm{e})$ and (f) $])$

(a), (c), and (e) Tubes for visual observation that have amplified products with SYBR Green I under UV light. (b), (d), and (f) DNA gel staining with ethidium bromide. Lane N, no template control.

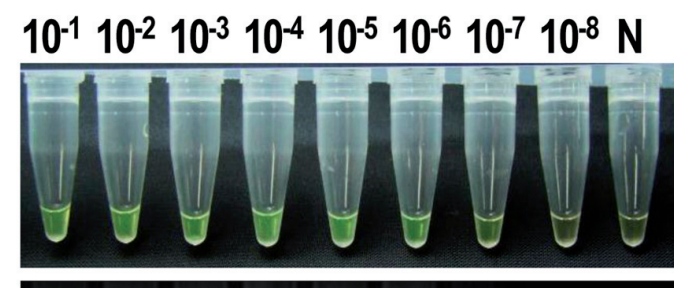

(b)

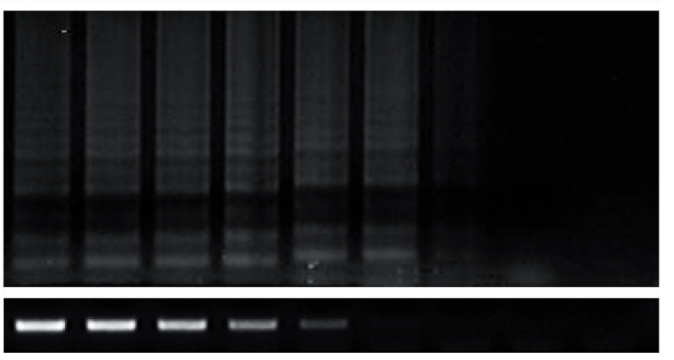

Fig. 5

The sensitivity of LAMP reaction for curtoviruses using universal primers (a) Products from the LAMP reaction with SYBR Green I under visible light. DNA gel staining with ethidium bromide (b) LAMP products and (c) PCR products. Lane N, no template control. 
2011-2012, and by a grant (Project Code No. 311058-05-3-HD140) from the iPET (Korea Institute of Planning and Evaluation for Technology in Food, Agriculture, Forestry and Fisheries), Ministry for Agriculture, Food and Rural Affairs, Republic of Korea.

\section{References}

Adams MJ, King AMQ, Carstens EB (2013): Ratification vote on taxonomic proposals to the International Committee on Taxonomy of Viruses. Arch. Virol. 158, 2023-2030. http://dx.doi.org/10.1007/s00705-013-1688-5

Bennett CW (1971): The curly top disease of sugarbeet and other plants, Monogr. No. 7. The American Phytopathological Society, St. Paul, MN.

Chen L-F, Brannigan K Clark R Gilbertson RL (2010): Characterization of curtoviruses associated with curly top disease of tomato in California and monitoring for these viruses in beet leafhoppers. Plant Dis. 94, 99-108. http://dx.doi. org/10.1094/PDIS-94-1-0099

Crowther J (1998): Detection of viruses in livestock. Parasitology 117, 29-40. http://dx.doi.org/10.1017/ $\underline{\text { S0031182099004199 }}$

Danks C, Barker I (2008): On-site detection of plant pathogens using lateral-flow devices. Bull. OEPP 30, 421-426. http://dx.doi.org/10.1111/j.1365-2338.2000.tb00922.x

Dellaporta SL, Wood J, Hicks JB (1983): A plant DNA minipreparation: version II. Plant Mol. Biol. Rep. 1, 19-21. http:// dx.doi.org/10.1007/BF02712670

Elmer JS, Sunter G, Gardiner WE, Brand L, Browning CK, Bisaro DM, Rogers SG (1988): Agrobacterium-mediated inoculation of plants with tomato golden mosaic virus DNAs. Plant Mol. Biol. 10, 225-234. http://dx.doi.org/10.1007/ $\underline{\text { BF00027399 }}$

Fauquet CM, Stanley J (2003): Geminivirus classification and nomenclature: progress and problems. Ann. Appl. Biol. 142, 165-189. http://dx.doi.org/10.1111/j.1744-7348.2003. $\underline{\mathrm{tb} 00241 . \mathrm{x}}$

Fukuta S, Kato S, Yoshida K, Mizukami Y, Ishida A, Ueda J, Kanbe M, Ishimoto Y (2003): Detection of tomato yellow leaf curl virus by loop-mediated isothermal amplification reaction. J. Virol. Methods 112, 35-40. http://dx.doi. org/10.1016/S0166-0934(03)00187-3

Hsieh CH, Wang HY, Chen YF, Ko CC (2012): Loop-mediated isothermal amplification for rapid identification of biotypes $B$ and $Q$ of the globally invasive pest Bemisia tabaci, and studying population dynamics. Pest. Manag. Sci. 68, 1206-1213. http://dx.doi.org/10.1002/ps.3298

Hur J, Choi E, Buckley KJ, Lee S, Davis KR (2008): Identification of a promoter motif involved in Curtovirus sense-gene expression in transgenic Arabidopsis. Mol. Cells 26, 131-139.

Kuan CP, Wu MT, Lu YL, Huang HC (2010): Rapid detection of squash leaf curl virus by loop-mediated isothermal amplification. J. Virol. Methods 169, 61-65. http://dx.doi. org/10.1016/j.jviromet.2010.06.017
Miller SA, Martin RR (1988): Molecular Diagnosis of Plant Disease. Annu. Rev. Phytopathol. 26, 409-432. http://dx.doi. org/10.1146/annurev.py.26.090188.002205

Minsavage G, Thompson C, Hopkins D, Leite R, Stall R (1994): Development of a polymerase chain reaction protocol for detection of Xylella fastidiosa in plant tissue. Phytopathology 84, 456-461. http://dx.doi.org/10.1094/ Phyto-84-456

Nie X (2005): Reverse Transcription Loop-mediated Isothermal Amplification of DNA for Detection of Potato virus Y. Plant Dis. 89, 605-610 .http://dx.doi.org/10.1094/ PD-89-0605

Notomi T, Okayama H, Masubuchi H, Yonekawa T, Watanabe K, Amino N, Hase T (2000): Loop-mediated isothermal amplification of DNA. Nucleic Acids Res. 28, e63-e63. http://dx.doi.org/10.1093/nar/28.12.e63

Park J, Hwang HS, Buckley KJ, Park JB, Auh CK, Kim DG, Lee S, Davis KR (2010): C4 protein of Beet severe curly top virus is a pathomorphogenetic factor in Arabidopsis. Plant Cell Rep. 29, 1377-1389. http://dx.doi.org/10.1007/ s00299-010-0923-8

Soto MJ, Gilbertson RL (2003): Distribution and rate of movement of the curtovirus Beet mild curly top virus (family Geminiviridae) in the beet leafhopper. Phytopathology 93, 478-484. http://dx.doi.org/10.1094/PHYTO.2003 $\underline{93.4 .478}$

Stanley J, Latham JR (1992): A symptom variant of beet curly top geminivirus produced by mutation of open reading frame C4. Virology 190, 506-509. http://dx.doi.org/10.1016/0042-6822(92)91243-N

Stanley J, Markham P, Callis R, Pinner M (1986): The nucleotide sequence of an infectious clone of the geminivirus beet curly top virus. EMBO J. 5, 1761-1767.

Stenger D, Ostrow KM (1996): Genetic complexity of a beet curly top virus population used to assess sugar beet cultivar response to infection. Phytopathology 86, 929-933. http://dx.doi.org/10.1094/Phyto-86-929

Stenger DC (1998): Replication specificity elements of the Worland strain of beet curly top virus are compatible with those of the CFH strain but not those of the Cal/Logan strain. Phytopathology 88, 1174-1178. http://dx.doi. org/10.1094/PHYTO.1998.88.11.1174

Stenger DC, Carbonaro D, Duffus JE (1990): Genomic characterization of phenotypic variants of beet curly top virus. J. Gen. Virol. 71, 2211-2215. http://dx.doi.org/10.1099/0022-1317-71-10-2211

Strausbaugh C, Wintermantel W, Gillen A, Eujayl IA (2008): Curly top survey in the western United States. Phytopathology 98, 1212-1217. http://dx.doi.org/10.1094/PHYTO-98$\underline{11-1212}$

Torrance L, Jones R (1981): Recent developments in serological methods suited for use in routine testing for plant viruses. Plant Pathol. 30, 1-24. http://dx.doi.org/10.1111/j.1365$\underline{3059.1981 . t b 01218 . x}$

Weiss JB (1995): DNA probes and PCR for diagnosis of parasitic infections. Clin. Microbiol. Rev. 8, 113-130. 